IdeAs

Idées d'Amériques

1 | 2011

Intégrations dans les Amériques

\title{
NAFTA, CAFTA and the Environment: The Role of Institutions
}

TLCAN, CAFTA y el medio ambiente: el papel de las instituciones

L'ALENA, l'ALEAC et l'environnement : le rôle des institutions

Sherrie Baver

\section{(2)enEdition}

Journals

Édition électronique

URL : https://journals.openedition.org/ideas/73

DOI : 10.4000/ideas.73

ISSN : $1950-5701$

Éditeur

Institut des Amériques

Référence électronique

Sherrie Baver, «NAFTA, CAFTA and the Environment: The Role of Institutions », IdeAs [En ligne], 1 |

2011, mis en ligne le 09 septembre 2011, consulté le 18 octobre 2022. URL : http://

journals.openedition.org/ideas/73; DOI : https://doi.org/10.4000/ideas.73

Ce document a été généré automatiquement le 18 octobre 2022.

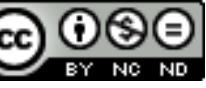

Creative Commons - Attribution - Pas d'Utilisation Commerciale - Pas de Modification 4.0 International - CC BY-NC-ND 4.0

https://creativecommons.org/licenses/by-nc-nd/4.0/ 


\title{
NAFTA, CAFTA and the Environment: The Role of Institutions
}

\author{
TLCAN, CAFTA y el medio ambiente: el papel de las instituciones
}

L'ALENA, l'ALEAC et l'environnement : le rôle des institutions

\section{Sherrie Baver}

\section{Introduction}

1 A deep scholarly divide exists over the benefits versus the costs of free trade agreements (FTAs), especially FTAs between countries at different levels of development such as NAFTA and more recently CAFTA-DR. ${ }^{1}$ These agreements have been part of the U.S. approach to neoliberal globalization starting in the $1980 \mathrm{~s},{ }^{2}$ and have been seen as the beginning of hemispheric integration under the once hoped-for Free Trade Area of the Americas (FTAA). Latin America moved toward these integration schemes, initially prompted in the late 1980s and early 1990s, by significant economic and political developments such as the debt crisis and end of the Cold War. Regional policymakers were forced to rethink their approaches to economic growth, moving towards domestic economic liberalization and integration with world markets. Along with the lowering of tariff barriers in the 1980s and 1990s, came currency, fiscal, and financial reforms, all providing the context for several free trade agreements with first world countries. Mexico was the first Latin American country to enter into a free trade agreement with the United States and Canada in 1994, and other countries in the region have followed. Several Latin American countries have also entered into new integration agreements among themselves such as ALBA and MERCOSUR, which exclude their first world neighbors.

2 As discussion evolved toward the NAFTA agreement in 1994, a robust transnational activist coalition focused on demanding positive outcomes in Mexico in terms of economic gains, labor rights, and environmental protection (Carruthers 2008:137-160; 
Graubart 2008). Much debate occurred during negotiations and in the academic literature as to whether free trade is good or bad for the environment. This essay examines the institutionalization of environmental concerns, primarily focusing on NAFTA, and argues that the 1994 agreement should be seen as a positive first attempt to raise the profile of environmental concerns within discussions of expanding global trade. More specifically, NAFTA and subsequent U.S. FTAs have contributed to the growth of procedural environmental rights that have the potential to deepen democracy in the wider political system. Given that free trade agreements represent the U.S. approach to world trade at present, this paper takes the practical position that building on NAFTA's foundation, opportunities exist to continue promoting environmental sustainability within these agreements.

\section{Theoretical Overview}

\section{A. Environment, Development, and Trade: Differing Perspectives}

3 To date, how has social science dealt with the question" is free trade good or bad for the environment, especially in developing economies?" Economists find some plausibility in the notion of an environmental Kuznets curve of increasing growth and increasing emissions. They argue that in the early stages of development, if trade contributes to the increasing level of economic development, after reaching some income threshold, citizens will demand environmental protection. ${ }^{3}$ In fact, a more nuanced version of the hypothesis is that trade may advance economic growth, and ultimately environmental protection, but there must be a national commitment to effective environmental policy in tandem with commitments to trade liberalization. This analysis dovetails with the Inglehart notion based on several decades of analyzing public opinion globally, that socioeconomic change follows coherent and relatively predictable patterns. Further, he argues that after reaching some economic threshold when basic needs are met, a majority of a nation's citizens adopt "postmaterialist values," including demands for a clean environment (Inglehart 1995: 379-403). Documenting such long term trends, however, does not address the question of what should be done in the short term and medium terms in rapidly growing economies. Will these emerging economies follow the polluting path of the old industrializers or will they be able to "bend the curve" for a cleaner industrial development? (Naiam 2010:83) The scholarly debate is precisely on whether and how countries might "bend" the Kuznets curve.

4 Among academic analysts, some scholars believe free trade can help industrializing economies lessen the predicted tendency toward environmental degradation Ronie Garcia-Johnson, for example, promoted "the transfer of green technology and practices" argument in her 2000 study (Johnson 2000). In her research on Mexico and Brazil, Garcia-Johnson documented the role of transnational chemical corporations in promoting positive environmental practices via the "responsible care" program. Similarly, Mexican legal analyst, Ximena Aguirre Franco, analyzing how environmental compliance influenced mergers and acquisitions by foreign firms in Mexico, found that as a consequence of NAFTA, environmental legislation and compliance had improved as well as a "race to the top in cross-border acquisitions". A specific finding was that foreign firms were loathe to acquire firms with soil contamination problems, so both 
buyers and sellers in Mexico had economic and legal incentives to remediate the site (Aguirre Franco 2010: 65-87). Similarly, Maria Del Rosario Barajas E. et al. found that NAFTA was favoring less polluting industries in the northern maquiladora region of Mexico (Del Rosario Barajas 2007: 265-289). This position is, perhaps, efficiently summed up by David Stern who found that on two environmental markers, air pollution and energy efficiency, neither of the more extreme predictions (negative or positive) have occurred. Rather, trends present before NAFTA continue and in some cases improve post-NAFTA "but not yet in a dramatic way." (Stern 2007: 291-322) ${ }^{4}$

The opposite position held by some social scientists and many activists is that the present era of aggressive trade liberalization promotes materials-intensive unsustainable economic growth, destabilizes local communities, and worsens domestic inequality at the heart of many environmental ills. Authors such as Paehlke and Newell, for example, point to the numerous environmental struggles in Latin America and the rest of the developing world such as: unequal access to natural resources, the siting of hazardous facilities, and unequal access to participation in relevant policy arenas (Paehlke 2003). ${ }^{5}$

6 Scholars adopting a middle position on the trade-environment link have simply looked for common ground between environmental activists and proponents of free trade. One area of interest overlap is on eliminating subsidies "that are both environmentally harmful as well as trade distorting (Conca, Dabelko 2010: 122). ${ }^{6}$ Although perhaps adopting a more critical than moderate stance, Gallagher and Zarsky offer a measured analysis of the trade-environment link in their study of Mexico's Silicon Valley (Gallagher, Zarsky: 2007). Their argument is that the problem is not necessarily with trade itself but with specific practices and that free trade may promote sustainable development under certain conditions. Specifically, foreign direct investment (FDI) can aid developing country industries leapfrog to sustainable production systems; this means minimizing highly polluting production by adopting cleaner technologies. The key, however, is government policies in the developing country. Particularly beneficial domestic policies would involve improving national capabilities for innovation through education and training and supporting domestic companies with credit.

\section{B. The Role of Institutions}

7 Unlike some other social scientists, political scientists with an institutionalist focus have been generally positive about the long-term consequences of NAFTA for the environment and the architecture of FTAs. What is meant by the theoretical focus on institutional adoption and evolution over time? In the last two decades, neoinstitutionalism has taken center stage in the social sciences, and key questions concerning institutions are how they begin, persist, and evolve. Many social scientists use "institution" in a socio-cultural sense to indicate "habits, decision styles, and social norms" and argue that institutions persist due to "a logic of appropriateness." (March, Olsen: 1989) While for U.S. policymakers, environmental concerns are now embedded in free trade agreements as a socio-cultural norm, one can also consider institutions in a more limited sense, common in political science, as more or less as synonymous with "formal organizations." Viewed through this lens, institutions arise as a more intentional product of human design as happens in creating environmental mechanisms in free trade agreements. 
Often, neoinstitutionalists adopt a historical lens to track persistence or changes in institutions over time. Historical institutionalists hold that institutions are path dependent and difficult to change (March, Olsen: 1989). These historically-based institutional trajectories carry "the cumulative weight of past choices-which help shape actors' preferences, routines and expectations." (Rhodes 2006: p. xv.) Several political scientists have already analyzed the NAFTA environmental template and changes to it over time. Therefore, in addition to reviewing this literature and discussing key NAFTA institutions, the present essay also highlights the ways these institutions may promote procedural environmental democracy.

\section{The Historical Context of the Trade - Environment Link}

9 What was the context for the environmental negotiations building up to NAFTA in 1994 ?

10 Environmentalists first began to push for environmental considerations in trade discussions during the Tokyo Round of General Agreement on Tariffs and Trade (GATT) between 1973-1979; however, the first formal inclusion of environmental concerns in world trade negotiations was the creation of the Committee on Trade and Environment (CTE) of the World Trade organization (WTO) in $1994 .{ }^{7}$ Clearly, environmental concerns had permeated trade discussion by the mid-1990s since both the CTE and NAFTA's environmental side agreement came into being at the same time. Significantly, though, more progress has been made in NAFTA implementation and more recent U.S. bi- and multilateral FTAs than within the WTO and CTE. This may well be because fewer actors are involved in the U.S. FTAs than in the WTO with its 153 members. ${ }^{8}$

11 Israel signed the first free trade agreement with the United States in 1985 and is now the only U.S. FTA without an environmental side agreement or chapter. As NAFTA negotiations began in the early 1990s, an unrelated case at the GATT helped to mobilize a transnational network of North American environmental activists. The 1990-91 TunaDolphin dispute between the United States and Mexico provided a rallying point for activists who opposed the free trade pact. The American government (under pressure from domestic environmental groups) considered closing the U.S. market to Mexican tuna since the fish were not being caught in dolphin-free nets. The Mexican government argued that the U.S. position represented a classic case of "green protectionism" and took the case to the GATT. The trade organization supported the Mexican position, ruling against high U.S. environmental standards. This ruling mobilized environmentalists, who, now with some concrete evidence, feared that NAFTA would unleash an environmental "race to the bottom." By 1992, this worry prompted formation of an unusual, transnational coalition of labor, environmental, and consumer activists as negotiations for NAFTA proceeded; U.S., Canadian, and Mexican negotiators, well aware of the GATT decision and its potential after-effects (Chasek 2006: 243). As a result, the trade body's decision was quietly shelved and Canadian, U.S., and Mexican NAFTA negotiators came to accept the need for environmental (and labor) side agreements as part of the treaty. 


\section{The NAFTA Environmental Side Agreement}

Bank (NADB). The Bank was established in 1994 and mandated to fund environmenta and related infrastructure projects within a narrow area of the U.S.-Mexico border. ${ }^{10}$ After a decade in operation, the remit of the bank expanded; both the U.S. and Mexican governments passed legislation in 2004 to consider projects in Mexico up to 300 kilometers from the border while leaving the distance at 100 kilometers from the border on the U.S. side. As of August 2008, eighty-eight projects costing over $\$ 865$ million had been funded that dealt primarily with water, wastewater, solid waste, and air quality. About sixty percent of the projects were funded in Mexico and about forty percent in U.S. border communities. The NADB represents a positive beginning for environmental protection, but most analysts would agree that the bank is grossly underfunded. While it had roughly $\$ 450$ million in capital in 2007, the World Bank estimated it needed $\$ 25$ billion per year for ten years to address the region's needs (O'Keefe 2009: 452). Recently, some analysts have suggested expanding the Bank's geographical and functional mandate to fund infrastructure and development projects beyond strictly environmental ones (Selee 2009: 16-17). Indeed, since the Bank is the only existing bi-national entity promoting development-related projects, it is increasingly receiving proposals to promote economic development in migrant-sending communities. Funding such projects is unlikely, however, unless the Bank receives a large infusion of capital.

\section{NAFTA and Procedural Environmental Rights in Mexico}

To date, the most important NAFTA environmental institution, and the one most studied by political scientists is NAFTA's Commission on Environmental Cooperation (CEC). Specifically, the Commission is composed of three bodies: the Council, the Secretariat, and the Joint Public Advisory Committee (JPAC). The Council, made up of 
the environmental ministers of the three countries meets annually; its remit is to authorize release of environmental information and to initiate inquiries. The Secretariat, located in Montreal, produces reports and administers four specific program areas: 1) Environmental Information, 2) Environment, Trade, and Sustainability, 3) Pollutants and Health, and 4) Biodiversity Conservation. JPAC is a citizen advisory group made up of fifteen members who are appointed by the three member states. JPAC members serve as citizen advisors to the Council and Secretariat. Mumme and Lybecker's detailed study of the Montreal-based CEC secretariat shows how it has changed over the years to use its budget more effectively (Mumme, Lybecker 2008). ${ }^{11}$

Missing from the scholarly study, however, is a systematic discussion of NAFTA's Environmental Side Agreements and promotion of procedural environmental rights. What are these procedural environmental rights, formerly called "Principle 10 Rights" and now more likely to be called "access rights" or "environmental democracy"? These environmental access rights, the right to information, citizen participation, and justice in environmental matters, were first adopted as separate laws in the United States between the 1960s and 1980s. In 1992, these access rights were bundled into "Principle 10" of the Rio Declaration, the statement of principles emerging out of the United Nations Conference on Environment and Development in Rio de Janeiro. In 1998, the United Nations Economic Commission on Europe (UNECE) adopted this package of environmentally-related rights in its Aarhus Convention. These procedural environmental rights apply to all countries in the EU, but Aarhus is open to governments throughout the world and is now the global "gold standard" for procedural environmental governance (Pallemaertz 2006: 179-203). In short, the reason to care about these reforms is that information, participation, and access to justice are fundamental in developing good governance and sustainable development in every country (Payne 2007). Many "low quality democracies" (and autocracies) acknowledge and may permit these rights in the environmental area, without allowing them more widely. Still, many environment and democracy promoters see the potential for spillover effects from rights in the environmental sphere to the larger political arena.

\section{A. The Right to Information}

The right to information is the first procedural right demanded by environmental democracy activists. While NAFTA may not have been directly connected to Mexico's Freedom of Information Act, environmental activists who had "cut their teeth" on winning NAFTA's environmental side agreement were key players in Mexico's adopting its Ley Federal de Transparencia y Acceso a la Información Pública Gubernamental (LFTAIPG) soon after the transition election of President Vicente Fox in 2000. Furthermore, NAFTA did require a Pollution Release and Transfer Registry (PRTR) or a Registro de Emisiones Toxicos y Contaminantes (RETC) in Spanish; and as Raul Pacheco Vega has argued, it is difficult to imagine a PRTR without a Freedom of Information Act. The point of a pollution registry, a report of pollution emitted by factories or other polluting operations, is to change behavior of polluters through indirect civil society pressure; and PRTRs are considered an essential part of "Community- Right- to- Know" laws. NAFTA's CEC has fostered and funded transnational NGO coalitions and these coalitions have been important in getting Mexico's PRTR reporting methodology to converge with those of the United States' TRI and Canada's NPRI (Pacheco-Vega 2007: 
271). Additionally, although Mexico, as a NAFTA signatory, was obligated to develop a PRTR, it started as an entirely voluntary exercise, unlike the U.S. and Canadian mandatory registries. Through the work of the CEC and the NGOs, Mexico's PRTR became mandatory and publicly accessible in December 2001. Still, the first annual report was only published in August 2006, due to industry efforts to block implementation. In short, the CEC saw as one of its key project areas to: 1) make Mexico's PRTR mandatory, 2) harmonize all three countries' PRTRs, and 3) disseminate much other environmental data electronically. The CEC secretariat claims to be one of the first international organizations to make its data available via the internet.

\section{B. The Right to Participation}

18 At least initially, the Commission on Environmental Cooperation worked on promoting the "Right to Participate in Environmental Decision making." Citizens of any of the three nations can bring complaints to the CEC Secretariat in Montreal or through the JPAC. Complaints are made through what is known as the Articles 14 and 15 Citizen Submission process. As of mid-2010, citizens or groups had launched 27 complaints against the Canadian government, 38 against Mexico, and 10 against the United States for non-enforcement of domestic environmental laws. ${ }^{12}$

In addition to previously-cited Mumme, Lybecker and Pacheco Vega, political scientists John Kirton, Virginia McLaren, and Jordi Diez, also support the general claim that by providing openings for citizen participation, the CEC has led to some positive environmental outcomes (Kirton McLaren 2002; Diez 2006). Longtime political analysts of global environmental governance, James Gustave Speth and Peter Haas characterize NAFTA and its CEC as "almost unprecedented in international relations because it gives NGOs and other non-state actors the right to formally challenge the legitimacy of governments' actions. ${ }^{13}$ Furthermore, the Council, with representatives from the national environmental agencies of Canada, the United States, and Mexico, has supranational authority to invoke sanctions, including trade sanctions if member countries fail to enforce their own domestic laws. This was the first trade-linked institution to open avenues to environmental groups to lodge complaints against any of the three NAFTA members; it provides a new tool for citizens, especially in Mexico with its weaker regulatory capacity, to hold their government and the private sector accountable in cases of environmental abuse.

A brief comparison between the NAFTA's CEC and the WTO's Committee on Trade and the Environment (CTE) illustrates the small but significant institutional advances the CEC represents in supranational environmental governance and specifically citizen participation. Unlike NAFTA's Commission, the remit of the WTO's CTE is only to examine: eco-labeling, the WTO's interaction with MEAs (of which there are now approximately 700), and the effects of domestic environmental measures on market access. The CTE, however, cannot make binding recommendations. Finally, there is significantly less room for citizen participation in the CTE than in NAFTA's CEC. While NGOs and other civil society groups have gained some presence in CTE discussions since the Cancun Ministerial in 2003, citizens are only beginning to play the roles of: 1) trade policy monitors, 2) technical knowledge providers, 3) information disseminators, and 4) capacity builders, roles NGOs and others have played in NAFTA and other U.S.-FTAs for over fifteen years (Cameron 2010: 176; Chasek op. cit.: 244, 260). 
21 To sum up the state of citizen participation in NAFTA, Speth and Haas, for example, temper their praise noting that even with the formal ability of NGOs and other nonstate actors to file petitions, and though several petitions have been filed since 1994, few challenges have achieved results. ${ }^{14}$ Thus, similar to other political scientists, Speth and Haas conclude that NAFTA's environmental side agreement represents only a firststep in an ongoing process of including citizen participation in trade -related environmental institutions.

\section{Right to Justice in Environmental Matters}

22 The third right, to justice in environmental matters, is, perhaps, the hardest procedural right to gain in most countries of the world. Aguirre Franco argues that NAFTA was responsible for Mexico's establishing its Federal Prosecutor for Environmental Protection (PROFEPA) in 1992. PROFEPA was created given the pressure to create modern environmental legislation and standards (Aguirre Franco op. cit.: 73-74). PROFEPA is part of Mexico's Environmental Ministry, which became known in 2000 as SEMARNAT

Briefly comparing the "children of lead" case in Torreon, Mexico, in which plaintiffs used the Mexican courts to try to win an environmental remedy and the "Cozumel" case using the NAFTA Article 14-15 complaint submission process illustrates how NAFTA began to offer Mexicans a potential avenue for environmental justice. Political scientists, Jordi Díez and Reyes Rodríguez, analyzed the Torreon case in detail, highlighting the difficulty of attaining legal redress through the courts. This case involved a Mexican public corporation, Met-Mex Peñoles, the largest silver producer in the world, and the extensive, impoverished barrio surrounding the plant. The plant's pollution posed serious health risks for decades to the barrio's children, with the first complaint filed against the plant with the Federal Ministry of Health in 1961. Various studies and complaints followed until 1998 when a local physician went public about the high lead levels in local children; he launched a health crusade, complaining to various government ministries and to the media. While this case would have all the makings of an "environmental justice" suit in the United States with some chance of success, it gained little traction in Mexico, a country where the notion of class-action suits is not part of legal proceedings and where establishing a firm's direct responsibility for harm with compensation is almost impossible (Díez Rodríguez 2008: 161-181).

A contrasting legal strategy was adopted in the 1996-1997 Cozumel case.

Cozumel represented a successful challenge brought by transnational activists and provides an example in which the "Article 14-15 process" of NAFTA's environmental side agreement worked as intended. As the Mexican government planned a large development in Cozumel involving a pier, shopping mall and golf course, environmentalists demanded a natural protected area and alleged that the government had not followed the required Environmental Impact Assessment (EIA) process for the proposed development. Lacking "green standing" in Mexican courts, local environmental NGOs used the NAFTA process instead. This represented the first successful case to go through the entire Article 14- 15 process, and the decision resulted in Cozumel creating a protected area and terminal port but not the much larger development originally proposed. The case also raised public awareness and put 
pressure on Mexico's Federal Attorney for Environmental Protection to enforce laws and regulations more effectively.

Impressively, in a 1996-1997 case, the NAFTA Article 14-15 process achieved environmental justice in a way that could not be achieved through the Mexican court system. Unfortunately it is possible that owing to this success, the three NAFTA governments have made the citizen submission process more difficult (Alanis Ortiz 2002: 186). In sum, NAFTA's submission process has the potential for serving as an effective dispute resolution mechanism, but at present, the parties seem unwilling to allow it that authority. ${ }^{15}$

\section{NAFTA 's Contribution to Institutionalized Environmental Governance}

The U.S. now has numerous bi- and multilateral trade agreements with countries around the world, and the argument presented here is that since the NAFTA template in 1994, it is no longer possible for the United States to negotiate a trade agreement without including an environmental (and labor) side agreement or chapter, and dispute resolution mechanism. Environmental inclusion became formalized with President Bill Clinton's Executive Order 13141, announced in preparation for the WTO ministerial summit in 1999, which mandated environmental reviews for all U.S. trade agreements and included a public comment provision. Congress moved this environmental concern from an executive order to law beginning with the Trade Act of 2002. It contained a general commitment to promote MEAs (but specific MEAs were not included) and also the general notion that sanctions were an option instead of limiting punishment to fees for violating labor and environmental protections.

Although we cannot argue that the environmental language each U.S. FTA since NAFTA showed more specific concerns enforcement "teeth" over time, the trend is in that direction. Environmental concerns have moved into the text of the agreements (they are no longer side agreements) and they also have an explicit role in promoting the institutions of democratic environmental governance. ${ }^{16} \mathrm{~A}$ comparison of two western hemisphere trade agreements since NAFTA, the Central American and Dominican Republic Free Trade Agreement (CAFTA-DR) of 2004 and the U.S- Peru FTA of 2009 will highlight these points.

In reality, then, free trade agreements must be seen as a mixed blessing for the environment, and CAFTA-DR represents the slow and non- linear trajectory of progress. Notably, CAFTA-DR aroused even more environmental opposition than NAFTA because of the inability of the Central American governments involved to enforce environmental standards (Abetti 2008: 14). Still CAFTA-DR has an environmental chapter (Chapter 17) within the agreement, set up a joint environmental affairs council similar to NAFTA's JPAC, and has a Secretariat in San Salvador within the Central American Commission for Environment and Development (CCAD). It has a consulting process for environmental dispute resolution and strengthened requirements for citizen participation. This environmental chapter (and more recent ones in U.S. FTAs) represents joint commitments to environmental cooperation. The goal is to identify specific areas of environmental concern and develop work programs that are in fact not specifically linked to trade liberalization. Funding for these projects is available through the joint U.S. EPA- U.S. AID program on environmental capacity building. For 
CAFTA-DR, capacity building involves: strengthening institutional and legal frameworks, increasing compliance and implementation of Multilateral Environmental Agreements (MEAs), creating an air pollution monitoring network, improving wastewater regulations, improving solid waste management, establishing a safe chemicals management program, and implementing Pollution Release and Transfer Registries. The environmental chapter requires the parties to create rosters of environmental experts to serve when disputes arise. Finally, the U.S. agencies are also giving technical assistance and training to officials in the region charged with environmental law enforcement and implementation. By offering training to judges, lawyers, and bureaucrats in aspects of environmental law and violations enforcement, citizens of these countries may slowly begin to exercise their right to justice in environmental matters. ${ }^{17}$

Similar features are included in all recent FTAs since CAFTA-DR. However, there is a potentially troubling environmental downside to NAFTA, CAFTA-DR and later U.S. FTAs. NAFTA's Chapter 11 provisions, repeated in CAFTA-DR and subsequent FTAs is that multinational corporations (MNCs) can challenge domestic legislation on natural resource development in closed-door international tribunals; thus, a host state may end up with little say in disputes involving, for example, mining or drilling including environmental impacts. ${ }^{18}$

Apart from these concerns about the natural resource sector, environmentalists have continued to make slow progress in later U.S. FTAs. Van Roozendaal traces the changes from the U.S.-Jordan FTA in 2000 to the 2007 Trade Act and the U.S.-Panama FTA of 2007 (still unratified by Congress). The key point of the 2007 acts and subsequent FTAs is that they signal "a shift from non-committal references to stronger commitments to the environment" as demanded by Congress (Van Roozendaal 2009: 431). First, seven specific Multilateral Environmental Agreements (MEAs) have been included in all trade agreements starting in 2007. Second, no longer does the FTA language make the distinctions between countries at different levels of development. Third, countries are now obliged not merely urged to maintain high environmental standards rather than lowering them to attract trade, and fourth, environmental obligations will be enforced with remedies, procedures, and sanctions similar to commercial obligations. Environmental violations will no longer be limited only to fines (op. cit.:436).

Since the U.S.-Panama FTA remains unratified by Congress (as of mid-2010), the U.S.Peru FTA (ratified and in force as of 2009) is now considered "the gold standard" for environmental chapters of FTAs. ${ }^{19}$ Sikina Jinnah provides specifics on how the Peru FTA provided a "regulatory transference mechanism" or leverage to provide a weaker multilateral environmental treaty with the ability to borrow enforcement power from a much stronger trade agreement to fulfill an environmental objective. In this case, a major environmental goal was to save Peruvian mahogany forests, which had been weakly protected from illegal logging under the 1973 Convention on International Trade in Endangered Species (CITES). CITES is one of the seven MEAs included in all U.S. FTAs since 2007. Jinnah's main interest in CITES and the Peru FTA's Annex on Forest Governance is that covered MEAs were included in NAFTA but disappeared from U.S. FTAs until 2009 "when they reemerged in a much stronger form." (Jinnah 2010: 12, 14-16.) harvesting, she is aware of the costly social dislocations that FTAs can cause. The 
Peruvian implementation of the trade agreement involved presidential decrees that had widespread implications for indigenous land use and tenure, which led to major demonstrations in Bagua Province in June 2009. Still, Jinnah argues that the problem was not the trade agreement itself but rather the lack of the fundamental access right of participation in environmental decision making that enraged the residents of the Peruvian Amazon. ${ }^{20}$

\section{Conclusion} agreements with Zepeda, Wise and Gallagher's 2009 report? (Zepeda 2009: 16). In their fifteen- year review of NAFTA's environmental effects, they found that in recent years, Mexico had weakened its commitment to environmental protection in manufacturing, in expanding industrial agro-export farms, in increasing water use in water-stressed regions, and in increasing use of nitrogen and other agro-chemicals.

Despite some protectionist backlash in response to the recent global financial crisis, free trade agreements remain at the core of global economic activity. ${ }^{21}$ What this essay has argued is that trade and environmental protection are not necessarily opposed to each other and trade agreements may, indeed, facilitate some improvement in environmental protection.

Trade agreements have not promoted a regulatory race to the bottom. Environmentalists have seen a degree of success by having environmental issues addressed in the body of the FTAs, in side agreements on environmental cooperation, and through funding for capacity building and technical assistance programs (Hornbeck 2007: 30). Yet, activists must work to expand upon the environmental chapters in these accords, including demanding improvements in enforcement language, increased funding for technical assistance, and establishment of institutions of modern environmental governance.

NAFTA's environmental agreement was highlighted because it has served as an institutional template for subsequent U.S.-FTAs. It has also served to link trade and environmental concerns in non-U.S. economic integration schemes within the Latin American region such as ALBA and MERCOSUR (O'Keefe op. cit: 50). Perhaps the environmental institutions established in NAFTA and later U.S. FTAs might eventually push WTO members to move towards more transparency and public participation for its Committee on Trade and the Environment.

How do we mesh our somewhat positive assessment of NAFTA environmental side Our response must be that embedding environmental institutions in trade agreements and in domestic political systems, more generally, is a long-term process. A new legal requirement or establishment of a formal environmental cooperation commission is only a start; but it is a concrete tool for scholars as well as environmental activists. Formally, this would mean that citizens of any country belonging to an FTA would have access to relevant information, participation, and complaint adjudication through the environmental commission. As new issues emerge, it is better to have an established entity than to try to create one anew to promote issue linkages. Thus scholar Michele Betsill, for example, examines whether or not NAFTA's CEC might be the place to establish a North American carbon-trading system. In this way, the power and 
authority of NAFTA as part of a multilevel governance system might be expanded (Betsill 2009: 161-180).

In sum we agree with Ron Mitchell who writes, environmental institutions often seek to promote monitoring, capacity building, and project financing and "although institutions that induce such efforts seem likely, ultimately, to improve environmental quality, the fact that such efforts may take three, four, or more causal steps removed from such improvements" may provoke debate on whether these innovations have been successes or failures (Mitchell 2008: 104). Maybe scholars of environmental institutions are a patient lot but we believe that the innovations begun in NAFTA represent early steps in the slow greening of global trade.

\section{BIBLIOGRAPHIE}

Abetti, Pauline, "Congressional voting on DR-CAFTA: the ineffectiveness of environmental lobbying," Journal of Economic Policy Reform, vol.11, n¹, March 2008, pp. 11-20.

Aguirre Franco, Ximena, "Racing to the Top? Acquisitions as a Vehicle for Improved Environmental Performance in Mexico," Mexican Law Review, vol. II, $\mathrm{n}^{\circ} 2$, January-June 2010, pp. 65-87.

Alanis Ortiz, Gustavo, "Public Participation within NAFTA's Environmental Agreement: The Mexican Experience," in John Kirton and Virginia MacLaren, eds., Linking Trade, Environment, and Social Cohesion, Burlington, Ashgate, 2002, pp. 183-190.

Barajas E, Maria Del Rosario, et al., "Environmental Performance of the Assembly Plants Industry in the North of Mexico," The Policy Studies Journal, vol 35, n 2, 2007, pp. 265-289.

Betsill, Michele, "NAFTA as a Forum for $\mathrm{CO}_{2}$ Permit Trading," in Henrik Selin and Stacy VanDeveer, eds., Changing Climates in North American Politics, Cambridge, MIT, 2009, pp. 161-180.

Cameron, Hugo, "The Evolution of the Trade and Environment Debate," in Ken Conca and Geoffrey Dabelko, eds., Green Planet Blues, $4^{\text {th }}$ ed., Boulder, Westview, 2010, pp. 168-176.

Carruthers, David. V., "Where Local Meets Global: Environmental Justice on the U.S.-Mexico Border," in David V. Carruthers, ed., Environmental Justice in Latin America: Problems, Promise, and Practice, Cambridge, MIT, 2008, pp. 137-160.

Chasek, Pamela, David Downie and Janet Welsh Brown, Global Environmental Politics, $4^{\text {th }}$ ed., Boulder, Westview, 2006.

Conca, Ken and Geoffrey Dabelko, eds., Green Planet Blues, $4^{\text {th }}$ ed., Boulder, Westview, 2010.

Deere, Carolyn and Daniel Esty, eds., Greening the Americas: NAFTA's Lesson for Hemispheric Trade, Cambridge, MIT, 2002.

Diez, Jordi, Political Change and Environmental Policymaking in Mexico, New York, Routledge, 2006.

Díez, Jordi and Reyes Rodríguez, "Environmental Justice in Mexico," in David V. Carruthers ed., Environmental Justice in Latin America, Cambridge, MIT, 2008, pp 161-181. 
Esty, Daniel C., "Economic Integration and Environmental Protection," in Regina Axelrod, Stacy VanDeveer, and David Leonard Downie, eds., The Global Environment: Institutions, Law and Policy, Washington, D.C., CQ Press, 2011.

Gallagher, Kevin P. and Lyuba Zarsky, The Enclave Economy: Foreign Investment and Sustainable Development in Mexico's Silicon Valley, Cambridge, MIT, 2006.

Garcia-Johnson, Ronie, Exporting Environmentalism: U.S. Multinational Chemical Corporations in Brazil and Mexico, Cambridge, MIT, 2000.

Graubart, Jonathan, Legalizing Transnational Activism: The Struggle to Gain Social Change from NAFTA's Citizen Petitions, University Park, Penn State, 2008.

Grossman, Gene M. and Alan B. Krueger, “Economic Growth and the Environment," Quarterly Journal of Economics, n¹10, May, 1995, pp. 353-377.

Hall, Peter and Rosemary Taylor, "Political Science and the Three New Institutionalisms," Political Studies, vol. 44, issue 5, 1996, pp. 936-957.

Hornbeck, J.F., The Dominican Republic-Central America-United States Free Trade Agreement (CAFTADR), Washington: Congressional Research Service, October 10 - 2007.

Inglehart, Ronald, “Changing Values, Economic Development and Political Change," International Social Science Journal, n47, September 1995, pp. 379-403.

Jinnah, Sikina, "Enhancing Regime Effectiveness through Strategic Linkages: The Emerging Role of Bilateral Trade Agreements in MEA Implementation," Paper presented at the International Studies Association Annual Convention, New Orleans, LA, February 17-20, 2010.

Kirton, John and Virginia MacLaren, eds., Linking Trade, Environment, and Social Cohesion, Burlington, Ashgate, 2002.

Li, Quan and Rafael Reuveny, "Democracy and Environmental Degradation," International Studies Quarterly, vol. 50, issue 4, 2006, pp. 935-956.

March, James and Johan Olsen, Rediscovering Institutions: The Organizational Basis of Politics, New York, The Free Press, 1989.

Mitchell, Ronald, "Evaluating the Performance of Environmental Institutions: What to Evaluate and How to Evaluate It," in Oran Young et al., eds., Institutions and Environmental Change: Principal Findings, Applications, and Research Frontiers, Cambridge, MIT, 2008, pp. 79-114.

Mumme, Stephen and Donna Lybecker, "The Commission for Environmental Cooperation in North America: Lessons for Export?" Paper presented at the Latin American Studies Association Annual Meeting, Montreal, September 5-8, 2008.

Naiam, Adil, et al., "Environment and Globalization: Five Propositions," in Ken Conca and Geoffrey Dabelko, eds., Green Planet Blues, $4^{\text {th }}$ ed., Boulder, Westview, 2010, pp. 76-93.

Newell, Peter, "Contesting Trade Policy in the Americas: The Politics of Environmental Justice," in David V. Carruthers, ed., Environmental Justice in Latin America: Problems, Promise, and Practice, Cambridge, MIT, 2008, pp. 49-73.

O'Keefe, Thomas Andrew, Latin American and Caribbean Trade Agreements: Keys to a Prosperous Community of the Americas, Leiden, Martinus Nijhoff, 2009.

Pacheco-Vega, Raul, “Mexico's Pollutant Release Registry: Taking Stock, Looking Ahead," in Jonathan Fox, et al., eds., Mexico's Right to Know Reforms: Civil Society Perspectives, Washington, Woodrow Wilson Center, 2007, pp. 270-274. 
Paehlke, Robert C., Democracy's Dilemmas: Environment, Social Equity, and the Global Economy, Cambridge, MIT, 2003.

Palamaerts, Marc, "The Aarhus Convention: Engaging the Disenfranchised through the Institutionalization of Procedural Rights?," in Jessica Greene and W. Bradnee Chambers, eds., The Politics of Participation in Sustainable Development Governance, Tokyo, New York and Paris, United Nations University, 2006, pp. 179-203.

Payne, J. Mark, et al, eds., Democracies in Development: Politics and Reform in Latin America, Washington: Inter-American Development Bank, 2007.

Rhodes, R.A.W., Sarah Binder, and Bert Rockman, eds., The Oxford Handbook of Political Institutions, New York, Oxford University Press, 2006.

Seelie, Andrew, More than Neighbors: An Overview of Mexico and U.S.-Mexico Relations, Washington, Mexico Institute, Woodrow Wilson Center, 2009.

Speth, James G. and Peter Haas, Global Environmental Governance, Washington: Island Press, 2006.

Stern, David I., "The Effect of NAFTA on Energy and Environmental Efficiency in Mexico," The Policy Studies Journal, vol. 35, nº 2, 2007, pp. 291-322.

United Nations Environment Program, Negotiating and Implementing Multilateral Environmental Agreements (MEAs): A Manual for NGOs, Nairobi, UNEP, 2007.

Van Roozendaal, Gerda, “The Inclusion of Environmental Concerns in US Trade Agreements," Environmental Politics, vol. 18, $\mathrm{n}^{\circ}$ 3, May 2009, pp. 431-438.

Zepeda, Eduardo, Timothy Wise and Kevin Gallagher, Rethinking Trade Policy for Development: Lessons from Mexico under NAFTA, Washington: Carnegie Endowment for International Peace, 2009. Accessible at www.ase.tufts.edu/gdae/policy_research/Carnegie.html

\section{NOTES}

1. NAFTA refers to the North American Free Trade Agreement and CAFTA-DR is the Central American-Dominican Republic Free Trade Agreement.

2. To date (mid-2010), the United States has FTAs in effect with seventeen countries: Australia, Bahrain, Canada, Chile, Costa Rica, Dominican Republic, El Salvador, Guatemala, Honduras, Israel, Jordan, Mexico, Morocco, Nicaragua, Oman, Peru, and Singapore. Three more (Colombia, Panama, and South Korea) are awaiting congressional approval.

3. Quan Li and Rafael Reuveny, "Democracy and Environmental Degradation," International Studies Quarterly vol. 50, 2006, pp. 935-956. Also see Gene M. Grossman and Alan B. Krueger, "Economic Growth and the Environment," Quarterly Journal of Economics vol. 110 (May 1995): p.353, 369.

4. This is similar to the argument of Deere and Esty in Greening the Americas, Cambridge: MIT, 2002.

5. Also, Peter Newell, "Contesting Trade Policy in the Americas: The Politics of Environmental Justice," in David C. Carruthers, ed., Environmental Justice in Latin America, Cambridge: MIT, 2008, pp. 49-73.

6. Daniel C. Esty makes a similar point. See "Economic Integration and Environmental Protection," 2011.

7. The WTO replaced the GATT in 1994 and all FTAs are also being negotiated within the larger context of the WTO.

8. WTO members as of 2011. 
9. The three covered MEAs are: CITES, Basel Convention on Transboundary Hazardous Waste, and the Montreal Protocol on Ozone Depleting Substances. See, Sikina Jinnah, "Enhancing Regime Effectiveness through Strategic Linkages," paper presented at the ISA Annual Convention, New Orleans, February 17-20, 2010. pp. 14-16

10. Data on the Bank may be accessed at www.nadbank.org

11. These scholars, too, find that the targeted data the CEC's has collected show that no deterioration of environmental standards across the three nations has occurred.

12. http://www.cec.org (Registry of Citizen Submissions). Accessed 7/27/10.

13. UNEP, Negotiating and Implementing MEAs, Nairobi, 2007, p. ix.

14. A successful challenge needs a two-thirds vote from the three North American NAFTA members.

15. Interview with North American Commission on Environmental Cooperation, Montreal, March 18, 2011.

16. The environmental section of US-FTAs first moved from a side-agreement to the body of the agreement in the US-Jordan FTA (2000).

17. www.epa.gov/international/regions/sa/caftadr.html Accessed 1/13/2010).

18. Pacific Rim $v$ El Salvador, a case (still ongoing as of 7/2010) that may provide an environmentally negative precedent within CAFTA-DR and other FTAs. The case was brought by the U.S. subsidiary of a Canadian firm against the Salvadoran government. The Salvadoran government has rejected the firm's Environmental Impact Assessment for a gold mining project, and the firm has lodged a complaint via CAFTA's "investor-state dispute system" before a mediation panel at the World Bank. If the firm wins, El Salvador will be liable to pay millions of dollars in damages. See Kevin Gallagher, "Stop Private Firms Exploiting Poor States," www.Guardian.co.uk, 5 February 2010. Also, Gus Van Harten, "Thinking Twice about a Gold Rush," Columbia FDI Perspectives, n 23, May 24, 2010, www.VCC.Columbia.edu

19. Interview with Deputy Assistant USTR for Environment and Natural Resources, July 22, 2010.

20. "Peru's Natives Hail Decision to Overturn Logging Rules," New York Times, June 19, 2009, p. A.

13.

21. "Waiting for a Trade Policy," New York Times, July 6, 2010, p. A22.

\section{RÉSUMÉS}

Après avoir fait la part des différents arguments en présence concernant les liens entre commerce et environnement, je soutiens que l'un des aspects positifs, quoique sous-estimé, de l'ALENA (créée en 1994) et d'autres accords commerciaux récents - bi- ou multilatéraux - entre les Etats-Unis et certains pays en voie de développement, est la création de mécanismes spécifiques visant à promouvoir la gouvernance environnementale et démocratique, ainsi que la protection de l'environnement. Bien que ces institutions formelles n'aient pas fait preuve, à ce jour, d'une grande autonomie ni d'une considérable efficacité, elles fournissent néanmoins aux groupes et réseaux domestiques et transnationaux de la société civile l'un des divers moyens d'affermir le rôle du citoyen dans la participation aux prises de décision environnementales, et ce à de multiples niveaux de la gouvernance. Elles peuvent également promouvoir un comportement d'entreprise positif dans les économies moins développées. Bien que les 
principales études de cas soient dévolues au Mexique et à l'ALENA, ces analyses peuvent également s'appliquer à d'autres pays d'Amérique Latine, comme ceux de l'ALEAC-RD et le Chili.

After sifting through the various arguments on the trade-environment nexus, I argue that an underrated positive feature on NAFTA (1994) and other recent U.S. bi- or multilateral trade agreements with developing countries, is creation of specific mechanisms to promote democratic environmental governance and environmental protection. While these formal institutions have not shown great autonomy and capacity to date, they provide one of several levers for domestic and transnational civil society groups and networks to enshrine a role for citizen participation in environmental decisionmaking at multiple levels of governance. They also may promote positive corporate behavior in less-developed economies. While the major case study focuses on Mexico and NAFTA, insights may also apply to other Latin American cases e.g. CAFTA-DR, and Chile.

Tras analizar en detalle los diferentes planteamientos sobre el vínculo entre comercio y medio ambiente, la autora sostiene que una característica positiva subestimada del TLCAN (1994) y otros acuerdos comerciales estadounidenses recientes, bilaterales o multilaterales, firmados con países en desarrollo, es la creación de mecanismos específicos destinados a promocionar una gobernanza medioambiental democrática, así como la protección del medio ambiente. Pese a que estas instituciones formales no han dado hasta la fecha grandes muestras de autonomía y capacidad, sí constituyen uno de los diversos incentivos que poseen los grupos y redes nacionales y transnacionales de la sociedad civil para confirmar el papel de la participación ciudadana en la toma de decisiones medioambientales en los distintos niveles de gobernanza. Dichas instituciones también pueden favorecer comportamientos empresariales positivos en las economías menos desarrolladas. Pese a que el principal estudio de casos se refiere a México y al TLCAN, debe atenderse igualmente a la contribución de otras experiencias en América Latina, como la del CAFTA-DR o Chile.

\section{INDEX}

Keywords : CAFTA, environmental democracy, institutions, international trade, Mexico, NAFTA

Mots-clés : ALEAC, ALENA, commerce international, démocratie environnementale, institutions, Mexique

Palabras claves : CAFTA, comercio internacional, democracia ambiental, instituciones, Mexico, TLCAN 